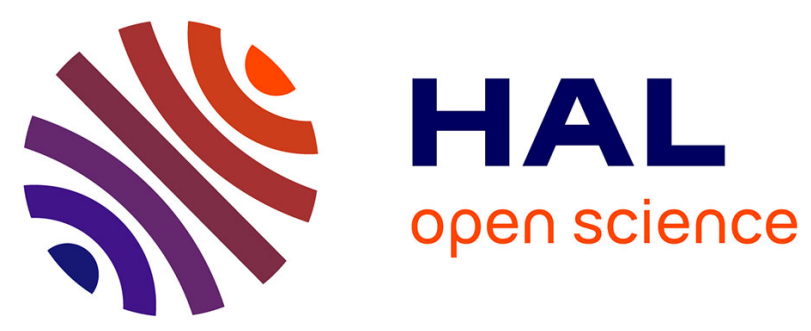

\title{
Configurational Attitudes
}

Pierre Pica, Johan Rooryck

\section{To cite this version:}

Pierre Pica, Johan Rooryck. Configurational Attitudes. Jose lema, Esthela Trevino. Theoretical Analyses of Romance Languages, Benjamins, pp.155-177, 1998. hal-00207634

\section{HAL Id: hal-00207634 https://hal.science/hal-00207634}

Submitted on 18 Jan 2008

HAL is a multi-disciplinary open access archive for the deposit and dissemination of scientific research documents, whether they are published or not. The documents may come from teaching and research institutions in France or abroad, or from public or private research centers.
L'archive ouverte pluridisciplinaire HAL, est destinée au dépôt et à la diffusion de documents scientifiques de niveau recherche, publiés ou non, émanant des établissements d'enseignement et de recherche français ou étrangers, des laboratoires publics ou privés. 


\section{Configurational Attitudes \\ Pierre Pica (C.N.R.S. - Paris) \& Johan Rooryck (Leiden University - HIL)}

\section{Introduction}

Usually, the problem of the interpretation of propositional attitudes and in particular the distinction between de dicto and de re readings of belief contents is considered to be a philosophical problem linked on the one hand to the theory of reference, and on the other hand to the cognate notion of truth value developed in analytical philosophy. To our knowledge, these issues have mostly been viewed as problems of philosophy of the mind, not issues to be addressed in syntactic terms. For example, the problem of de dicto and de re readings of sentences in belief contexts (Salmon \& Soames 1988), or the problem of de dicto, de re and de se readings in Oedipus wants to marry his mother/ Iocaste are viewed as philosophical issues, not as issues that belong to the Grammar, much less to the realm of syntax.

Let us take the following example:

Edipus thinks that he has killed his father

According to the philosophers of mind, this sentence has a de dicto reading in the context in which Edipus does not know that the person he killed was his father. This has for example led philosophers to believe that the problem de dicto/ de re was linked to the paradox of contradictory beliefs. As is well known, a person may believe that the entrance of the British Museum is guarded by two lions, and looking at the very same building from another side without knowing that it is the British Museum, this person may think that the entrance of that building, which she does not identify as the British Museum, is not guarded by two lions. Both the sentence She believes that the entrance of the BM is guarded by two lions and the sentence She believes that the entrance of the BM is not guarded by two lions can be uttered truthfully about the same person.

We want to argue that the debate around the de dicto/ de re distinction confuses two issues. First of all, it presupposes a theory of referentiality or extensionality according to which the sentence The BM which is this point on the map is a very beautiful building is a puzzle in itself, since once again the BM is conceived from two different points of view, hence belongs to the contradictory belief debate. We dismiss this problem altogether as an illusion, on linguistic grounds, since the head of a relative clause does not have reference. This suggests a strictly internalist approach to all aspects of language, including meaning, as argued at length in Chomsky (1993). The inquiry into (external) reference belongs to the study of the real world, and does not belong to the domain of the faculty of language.

Secondly, the issue of attributions of belief raised by the analytic philosophers within the debate on de dicto/ de re also revolves around reference of belief. Likewise, we will defend a purely internalist approach to the issue of attributing beliefs, and we will argue that it can be reformulated in internalist terms as the result of different syntactic configurations which derive different interpretations or propositional attitudes.

In our view, the problem of propositional attitudes should be analyzed in light of the linguistic notion of evidentiality (Chafe \& Nichols 1986). We propose that the 
notion of evidentiality should in turn be derived configurationally. This second issue will constitute the main focus of this article. In section 2, we will review Rooryck's (1995) recent proposal for a configurational representation of belief $(\S 2.1)$, showing that propositional attitudes involve the possession of an attitude, which is configurationally expressed. Next, we will illustrate some hitherto unobserved syntactic properties of attributed belief ( $\$ 2.2)$, involving extraction and Binding. The Binding facts will show that Binding theory is indeed part of the language faculty, but that the data Binding must account for are much more complex than is usually assumed in the literature. These observations will force us to revise Rooryck's (1995) analysis along the lines of Bonneau \& Pica's (1995) configurational theory of reference in DP. This reinterpretation will allow us to derive both the syntactic properties of attributed and what we will call 'directly attributed' belief $(\$ 2.3)$. In section 3, we would like to extend the analysis to socalled belief de se (Castañeda 1966). Belief de se will be argued to correspond once more to specific syntactic properties that can be configurationally derived.

\section{Two types of belief}

\subsection{Believe as a configurational construct}

Rooryck (1995) offers an analysis relating so-called 'Raising-to-subject' (SpecAGR $\mathrm{S}$ ) with verbs such as seem and 'Raising-to-object' (SpecAGR $\mathrm{OP}$ ) with believe type verbs. Rooryck (1995) views the relation between seem and believe in exactly the same way as the relation between be and have established by Freeze (1992), Hoekstra (1992) and Kayne (1993), implementing an insight of Benveniste's (1960). The configurations of be and have are represented in (2): (2a) illustrates the possessive construction of the Latin sentence sunt nobis mitia poma 'we have many apples', in which the $\mathrm{D}^{\circ} / \mathrm{P}^{\circ}$ head assigns dative case to the possessor. The corresponding configurations of seem and believe are represented in (3). In both cases, the relation between be/ seem and have/ believe is expressed by the fact that the dative-assigning head incorporates into be/ seem, deriving accusative havel believe. In this way, believe is the 'accusative' (HAVE) counterpart of 'nominative' seem (BE).

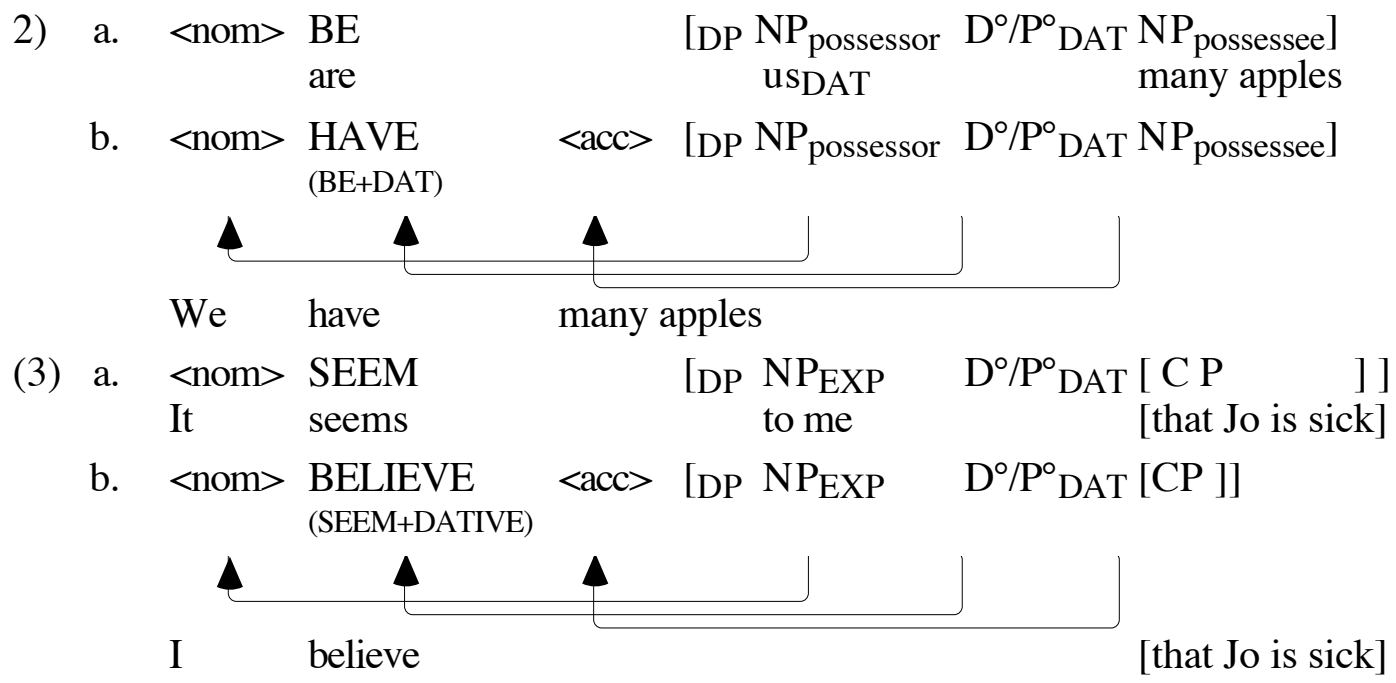


In a language such as Dutch, the relation between seem and believe is morphologically transparent, providing strong evidence for the derivations proposed in (3): 1

(4) a.
$\mathrm{Me}$
dunkt
[CP dat Jan ziek is]

to-me DAT think3P.SG

that Jan sick is 'It seems to me that Jan is sick'

b. Ik denk [CP dat Jan ziek is]

I think that Jan is sick'

The presence of a dative $\mathrm{D}^{\circ} / \mathrm{P}^{\circ}$ projection as the locus of the Possessor/ Experiencer in (4) derives the fact that both seem and believe are verbs expressing propositional attitudes. The interpretive status of the sentential complement is related to a judgment on behalf of the Experiencer.

Rooryck (1995) attempts to derive the semantics of seem and believe configurationally. Taking seriously the strong morphological correlation between verbs of comparison and seem type verbs in many languages, ${ }^{2}$ he argues that seem involves a comparative element as in (5a) which ensures an interpretation as in (5b):
(5) a. It seems (to me) that/ like/ as if Alfred has eaten his veggies
b. There is an event right now (= it) that is similar to
the set of events in which Alfred has eaten his veggies

More importantly, however, the comparison involved in seem is argued to be expressed configurationally as a relation between two events: a nonexpletive (pro$\mathrm{CP})$ it and the CP complement of seem. ${ }^{3}$ In ECM and Raising contexts, the comparison between two events takes place within the complement $\mathrm{CP}$. In this case, Rooryck (1995) argues that IP moves to SpecCP, and that the configurational comparison is between the IP in SpecCP and its trace. This movement derives three things. First, the subject of IP is allowed to move into the matrix clause, without

\footnotetext{
1 We will not offer an explanation for the fact that the Experiencer of believe can be marked either with dative or with nominative case in various languages. Such is the case in certain dialects of English for think (Methinks that you are wrong). In Icelandic, the subject of believe may show up in ECM contexts as a dative Experiencer, while the subject of the infinitive is marked with Nominative case by the matrix verb (Sigurdsson 1989). Swedish tycka 'believe' is related to the Icelandic form for think, but has a nominative-accusative structure. The reasons for this variation must be relatively superficial: certain (lexical) Cases seem to directly express thematic roles (dative - Experiencer), while accusative Case is more structural in nature. The analysis developed in the text strongly argues for a close relation between (dative) seem and (dative/accusative) believe.

The close relation expressed in (4) does not seem exceptional: in French, there is an impersonal construction with croire 'believe' that semantically corresponds to seem, as in (i):

i. Il est à croire que Jean est malade

It is to believe that John is sick

'It seems that John is sick'

2 e.g. Dutch lijken 'seem' and vergelijken 'compare', French sembler 'seem' and ressembler 'resemble', paraître 'seem' and comparer 'compare', Spanish parecer 'seem' and comparar 'compare', English be likely, like, alike, and liken.

3 Since believe is derivationally related to seem, it must involve the same semantics. Rooryck (1995) assumes that in believe contexts, the comparison between two events obtains by the relation at LF between the moved sentential complement in SpecAGR $\mathrm{O}^{\mathrm{P}}$ and its trace.
} 
causing improper movement. Secondly, there is no need for $\mathrm{CP} / \mathrm{S}^{\prime}$ deletion or special IP complementation in the case of raising verbs. Thirdly, movement of IP to SpecCP can be assimilated to a type of Focus movement in which an event type (the IP in SpecCP) is related to an event token (the trace (variable) of that IP). This can be related to the fact that the copy of IP represented by the trace is not fully identical to the IP in SpecCP, but rather must receive an interpretation in terms of parallelism, reminiscent of ellipsis (See for discussion Chomsky 1995:253). Rooryck (1995) claims that the relation between the IP in SpecCP and its trace is one of comparison between an event type (or set) and its token. As a result, failure of IP movement results in an uninterpretable configuration.

(6) Sue believes Alfred to be sick

Sue [XP believes[AgOP Alfred $\left.\mathrm{t}_{\mathrm{V}^{\circ}-\mathrm{AgO}^{\circ}}\right]$ [ [VP $\mathrm{t}_{\mathrm{V}^{\circ}}\left[\mathrm{CP}\left[{ }_{\mathrm{IP}} \mathrm{t}_{\mathrm{Alfred}}\right.\right.$ to be sick] $\left.\left.\mathrm{C}^{\circ} \mathbf{t}_{\mathbf{I P}}\right]\right]$

(7) Alfred seems to be sick

[IP Alfred [seems]AGRS] [vP $\mathbf{t}^{\circ}$ [CP [IP $\mathbf{t}_{\text {Alfred }}$ to be sick] [C, $\mathrm{C}^{\circ} \mathbf{t}_{\mathbf{I P}}$ ]]

In the cases of raising, the comparative meaning of seem/ believe is thus configurationally derived via Focus movement within the complement CP. Believe and seem involve a propositional attitude via the Possessor/ Experiencer in the dative projection. As a result, ECM believe and raising seem need no longer be marked as such in the lexicon. Seem and believe are underlyingly identical, and only involve slightly different case configurations. We would like to conclude more generally that propositional attitudes (belief, judgment, desire) are configurationally expressed as the possession of an attitude indicated by the explicit or implicit presence of a dative. In the case of seem and believe, the notion of attitude can be reduced to a particular type of Focus which involves comparison.

\subsection{Problem: 'indirectly attributed' belief}

Although the configurational derivation of believe presented in the previous section has a number of attractive features, there are strong indications that it cannot be the whole story. Besides the use of seem/believe with a Possessor/ Experiencer in the contexts defined above, there is a range of contexts in which the subject of belief should rather thematically be interpreted as a Recipient of belief. We will define these contexts as instantiations of 'indirectly attributed' belief, and refer to the seem/ believe configurations of (6-7) as 'directly attributed' belief contexts. Let us first informally define the notion of 'indirectly attributed' belief as in (8):4

4 We insist that the definition in (8) is meant only as an informal, descriptive approximation. What we will call 'indirectly attributed' belief is only properly defined by the cluster of formal properties that we describe below, and ultimately by the configuration that derives these observations. Secondly, it is important to distinguish 'indirectly attributed' belief from 'caused' belief as in I will make Mary believe that John is sick. Although 'caused' belief may also involve a belief that is factually incorrect, we do not think that it involves 'indirectly attributed' belief in the sense intended here. Note that 'caused' belief falls outside the scope of the informal definition in (8), and also that the various island effects and Binding restrictions observed below for 'indirectly attributed' belief do not hold for 'caused' belief, as the reader may check for him/herself. 
'indirectly attributed' beliefs include those beliefs which the subject of believe may possibly not hold him/ herself, but which are indirectly attributed to the subject .

A few examples may make this clearer. In (9), the adverbs bien 'certainly' and probablement 'probably' contribute to an interpretation of croire 'believe' in which there is no assertion that Jean believes the propositional content of the complement clause, but the sentence is presented rather as a conjecture, a supposition that this is what Jean believes.

(9) a. Jean croira bien que cette personne a été condamnée

'Jean will certainly believe that this person has been convicted'

b. L'ennemi croit probablement que cette personne a été condamnée

'The enemy probably believes that this person has been convicted'

The conjecture on behalf of the speaker corresponds to an 'attribution' of belief to Jean. In thematic terms, one might say that the subject does not 'have' the propositional contents him/herself, but rather 'receives' it in some indirect way. This 'indirect way' of holding a belief can be realized in various ways. For example, the belief expressed in (9a) can be attributed to Jean by the speaker, although this is not necessary. The sentence (9b) shows that the belief held by the enemy need not be attributed by the speaker, but might be attributed by 'our' counterintelligence services, for example. Importantly, we have no way of ascertaining whether the instance through which the belief is indirectly attributed to Jean is lying or not. The study of 'indirectly attributed' belief is then to a large extent a study of the different types of evidentiality.

The notion of 'indirectly attributed' belief is strongly related to the notion of evidentiality: in (9), the speaker has no direct evidence that Jean actually holds the belief the speaker attributes to him. This becomes even clearer in the contrast between (10a) and (10b). In (10a), the speaker-subject may have both direct and indirect evidence of Jean being wrong. In (10b), the speaker suggests that (s)he has additional, indirect evidence for Jean being wrong. This accounts for the strong 'I always knew' interpretation of the sentence: it will be felicitous in a context where the direct and patent evidence of Jean being wrong has just been brought to light, and in which the speaker alludes to being privy to some additional, undisclosed information or personal intuition about the case. This interpretive effect can be viewed as a result of the fact that in a context of 'indirectly attributed' belief, the subject is presented as having 'received' information from elsewhere.

(10) a.

Je croyais que Jean avait tort 'I believed that Jean was wrong'

b. Je croyais bien que Jean avait tort 'I already believed that Jean was wrong' (direct/ indirect evidence)

(indirect evidence only)

To keep terminology clear, we will view the notion of 'indirectly attributed' belief as the expression of a case of indirect evidentiality and 'directly attributed' belief as a case of direct evidentiality. Despite the intriguing interpretive effects of 'indirectly attributed' belief, the definition in (8) still has the flavor of a rather vague, discourserelated, pragmatic description in which thematic considerations (have vs receive) seem to play a role. In other words, it remains unclear whether the issue of attributed belief has any syntactic effects as well. In the remainder of this section, we would 
like to illustrate an array of syntactic effects that clearly demonstrate the syntactic relevance of the notion of 'indirectly attributed' belief.

First, we can observe that French ECM sentences with croire 'believe' as in (11) become unacceptable in a context of 'indirectly attributed' belief:

(11) a. Voilà la personne que Jean croira (*bien) avoir été condamnée injustement 'Here is the person who Jean will certainly believe to have been wrongly convicted'

b. Voilà la personne que Jean croyait (*probablement) avoir été condamnée injustement

'Here is the person who Jean probably believed to have been wrongly convicted'

Secondly, 'indirectly attributed' belief has intriguing effects on the use of the indicative or subjunctive mood in the complement clause of croire 'believe'. The complement clause of croire 'believe' requires indicative mood if the matrix clause is affirmative, and subjunctive mood if the matrix clause is negated. This is illustrated in (12ab). Interestingly, the requirement on subjunctive mood for negative croire 'believe' sentences is lifted in the context of 'indirectly attributed' belief as in (12c):

(12) a. Jean croit que Marie est/*soit malade

'Jean believes that Marie isIND/*SUBJ sick'

b. Jean ne croit pas que Marie est/ soit malade

'Jean does not believe that Marie isIND/SUBJ sick'

c. Jean ne croit probablement pas que Marie est/*soit malade

'Jean probably does not believe that Marie is IND/*SUBJ sick'

Thirdly, the context of attributed beliefs seems to create 'weak' island effects on extraction out of the complement clause of croire 'believe':

(13) a. Je me demande quel musée Marie croit (?(?) probablement) que Paul a vu?

'I wonder which museum Marie (probably) believes that Paul saw'

b. Je me demande combien Marie croit (*probablement)

que Paul a vu de musées?

'I wonder how many Marie (probably) believes

that Paul saw of museums'

Fourth, the Binding properties of $e n$ 'of it' and soi 'self' are very different in contexts of 'indirectly attributed' and 'directly attributed' beliefs. ${ }^{5}$ In the 'directly attributed'

5 In these cases, we systematically contrast sentences containing 'indirectly attributed' beliefs with sentences involving ECM, since we take the ECM cases with croire 'believe' to be the paramount cases of 'directly attributed' belief. We have found that believe sentences with tensed complements are ambiguous between 'indirectly attributed' and 'directly attributed' readings. Although adverbs such as probablement and bien select the 'indirectly attributed' reading, it is as easy to force 'directly attributed' readings with tensed complements. One way to achieve this is to combine a syntactic context which requires 'directly attributed' belief with the syntactic test involving en.

(i) ?? Je me demande combien ${ }_{j}$ Marie $_{i}$ croit que les gens en ${ }_{i}$ ont dit $\left[\mathrm{t}_{\mathrm{j}}\right.$ de mal]

'I wonder how much Marie thinks that people of-her have slandered' 
belief context of ECM, coreferentiality of en with an antecedent in the matrix clause is marginal (14a), while in 'indirectly attributed' belief contexts $e n$ can be coreferential with an antecedent in the matrix clause (14b):

(14) a. ?? Je me demande quelle personne Marie $_{i}$ croit en $_{i}$ avoir dit du mal 'I wonder which person Marie believes to have slandered her'

b. Paul Pe croit probablement pas que l'on en $_{\mathrm{i}}$ dit du mal 'Paul probably does not believe that people slander him'

c. Je me demande quelle personne Marie ${ }_{i}$ croit avoir dit du mal d'elle $e_{i}$ 'I wonder which person Marie believes to have slandered her'

Note that the marginal corefentiality between en and its antecedent is not the result of a more general restriction on the coreferentiality of pronouns: coreferentiality between Marie and the pronoun elle is perfectly possible as in (14c). With respect to the Binding properties of soi 'self', we observe that in ECM or 'directly attributed' belief contexts, coreferentiality between soi and an antecedent in the matrix clause is marginal and 'anti-local', as in (15a). Recall long distance soi is only permitted in subjunctives and infinitival complements, as noted in Pica (1987), cf (15b).

(15) a. ?? Je me demande quelles personnes les gens $s_{i}$ croient avoir dit du mal de soi $i_{i}$

'I wonder which persons people think to have slandered self'

b. L'on ${ }_{\mathrm{i}}$ souhaite/ $*$ dit toujours que les gens disent du bien de soi $\mathrm{i}_{\mathrm{i}}$

'One always wishes/ says that people say nice things about self'

In 'indirectly attributed' belief contexts, the anaphor soi can be coreferential with an antecedent in the matrix clause, even though the sentence is indicative (see also Sigurdsson 1990 for Icelandic). Interestingly, the complex anaphor soi-même does not share this property.

(16) a. L'on ${ }_{i}$ ne croit probablement jamais que

les gens ont dit du mal de soi $_{i}(*$-même)

'One probably never believes that people have slandered self'

b. L'on ne veut jamais croire que les gens disent du mal de soi ${ }_{i}(*$-même)

'One never wishes to believe that people have slandered self'

To our knowledge, this combination of properties of 'indirectly attributed' belief has not been observed before. Since the syntactic restrictions noted for 'indirectly attributed' belief seem to involve configurational conditions on movement and binding, it stands to reason that we would try to derive the restrictions noted in configurational terms. This entails that 'indirectly attributed' and 'directly attributed'

(ii)

?? Je me demande combien ${ }_{j}$ l'on $_{\mathbf{i}}$ croit que les gens ont dit

[ $\mathrm{t}_{\mathrm{j}}$ de mal] de soi $\mathrm{i}_{\mathrm{i}}$

'I wonder how much one thinks that people have slandered oneself'

This combination obtains in the sentences in (i-ii): combien extraction is only compatible with a 'directly attributed belief' reading of croire 'believe', since the 'indirectly attributed belief' reading, which creates a weak island for extraction of combien, would lead to an ungrammatical (*) sentence (cf the facts in (13)). Since the sentences (i-ii) have an intermediate (??) grammatical status, it must be the case that we are in the presence of the 'directly attributed belief' reading. The intermediate status of these sentences with tensed complements is exactly parallel to that of the ECM sentences with coreferential en in the text, as expected. 
beliefs correspond to different configurations with different syntactic and semantic properties. In the next section, we will develop an analysis that derives just that.

\subsection{The configurations of 'indirectly attributed' and 'directly attributed' belief}

Before we launch into the specifics of the configurational analysis proposed for 'indirectly attributed' and 'directly attributed' belief, we need to make explicit a number of background assumptions adopted here. As our starting point, we will take the assumptions developed by Bonneau \& Pica (1995) and Pica (1996), which develop certain aspects of the relation Kayne (1994) establishes between CP and DP. Bonneau \& Pica (1995) and Pica (1996) adopt the structure in (17) for the extended projections of both NPs and CPs:

$$
\left[\mathrm{DP} \_\mathrm{D}^{\circ}\left[\mathrm{CP} \_\mathrm{C}^{\circ}\left[\mathrm{IP} \_\mathrm{I}^{\circ} \mathrm{XP}\right]\right]\right.
$$

In this structure, $\mathrm{D}^{\circ}$ is the locus of 'deixis', and $\mathrm{C}^{\circ}$ is the locus of 'reference'. Movement is for interpretive purposes, rather than for reasons of feature checking (cf. also Barbiers 1995). Movement of XP to SpecCP allows for the XP to be included in the set of XPs, while movement of XP to SpecDP allows for an instantiation of XP as a member of the set of XPs (set inclusion). A DP such as the dog thus involves a complex representation in which the XP in (16) corresponds to the NP $d o g$, which gets its reference as a set by movement to SpecCP and its instantiation as a member of the set of dogs by LF movement to SpecDP.

We are now in a position to reinterpret Rooryck's (1995) analysis of 'directly attributed' belief. Movement of the IP to SpecCP turns that IP into the set of events; and movement of IP to SpecDP instantiates an element of that set. In this case, all movement is overt to allow the subject of IP to move further on to SpecAGR ${ }_{S} \mathrm{P}$ (seem) or SpecAGRoP (believe) of the matrix clause (cf. 17). The interpretive contribution of the DP projection in the complement of seem/ believe involves a special type of set inclusion, namely comparison. 'Comparison' is between SpecDP and SpecCP. 6

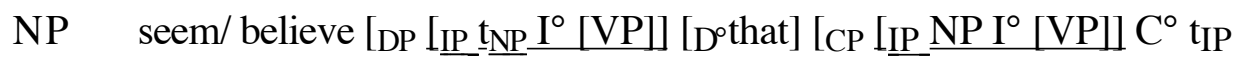

]]

This structure allows for an explanation of the fact that extraction in ECM contexts is fine, since the complement is interpreted as an argument of the matrix verb. The Binding facts present an paradox. Usually, en is viewed as an element that cannot be bound by an agentive subject (18a), while soi is viewed as an element that is preferably bound by an agentive subject (18b), (Ruwet 1992).

(19) a. * L'on $_{\mathrm{i}}$ veut que les gens en ${ }_{\mathrm{i}}$ disent du bien

'One would like that people say nice things about self'

\footnotetext{
6 For tensed complements of seem/ believe, we will assume that movement to SpecDP is covert. This will prevent that the subject of tensed clauses can be extracted to the matrix clause, as is the case for infinitives. Nevertheless, covert movement of tensed IPs to SpecDP does not entirely square with Rooryck's (1995) analysis, since he analyzes certain problematic ECM facts (DOC, Postal 1974) by an appeal to covert movement of infinitives as well (see Rooryck 1995 for discussion). We will leave this additional problem for further research.
} 
b. L'on ${ }_{i}$ veut que les gens disent du bien de soi $i_{i}$

'One would like that people say nice things about self'

We therefore expect both elements to be in complementary distribution. Surprisingly, however, both en and soi are marginally acceptable in ECM contexts (14a-15a). We want to argue that this is due to the fact that croire 'believe' involves possession, namely possession of a comparison under Rooryck's decompositional analysis of the pair seem/ believe. As a result, the subject of croire 'believe' can be interpreted either as a Recipient (have), deriving coreference with en, which typically prefers Recipients for its antecedent, or as an Agent (possess), which derives coreference with soi, which is known to be Agent-oriented. Since both interpretations of the matrix subject are possible at the same time, the examples involved have an intermediary status.

Let us now turn to the cases of 'indirectly attributed' belief. We have observed a series of paradoxes, which can be summarized in (20):

(20) a. Why is ECM impossible with 'indirectly attributed' belief?

b. Why are there 'weak island' effects on extraction?

c. Why is Binding with the subject of the matrix clause possible with en, and impossible with soi in contexts of 'indirectly attributed belief (contrary to the more 'usual' cases (19)?

We would like to propose that the configuration of the sentential complement in'indirectly attributed' belief contexts is quite different from the one proposed for 'directly attributed' beliefs. Let us again illustrate this for English believe. We would like to propose that the sentential complement of 'indirectly attributed' belief is an IP which has moved no farther than SpecCP, as in (21):

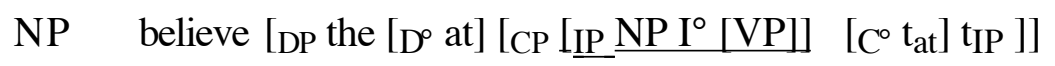

The complementizer that has a different status from that in 'directly attributed' beliefs. We argue that the complementizer has the status of a fully lexical element in (21), with full deictic force: the prepositional complementizer at overtly moves to $\mathrm{D}^{\circ}$, and merges with the in SpecDP at PF. The lexical status of the complementizer involving attributed belief is corroborated by its nondeletability. Bolinger (1972) observes that complementizers of propositional attitude verbs can freely delete if there is what he calls 'harmony' between the main clause and the sentential complement, while the complementizer cannot delete if there is no 'harmony' between both clauses (cf 22):

(22) a. John believes (that) the winner is Greek

b. John disbelieves *(that) the winner is Greek

In the context of Bolinger's observations, the notion 'harmony' clearly refers to the evidential status of both clauses. In evidential terms, it seems to be the case that if the epistemic state introduced by the main clause does not contradict that of the embedded clause, the complementizer deletes, while the complementizer is obligatory in cases where there is a conflict between the epistemic states (the evidential status) of both clauses. 
We have found that something similar is true in cases of 'indirectly attributed' belief: for a number of speakers, it is more difficult to delete that in 'indirectly attributed' contexts : 7

(23) a. John believes (that) the winner is Greek

b. John probably believes ?/??(that) the winner is Greek

Taking seriously the minimalist framework developed in Chomsky (1995), we assume that only functional elements can be deleted after spellout, while lexical elements cannot. If the complementizer that in (21) is viewed as a lexical element, its undeletability in (22b-23b) follows from its lexical status.

At first sight, the deictic interpretation of the sentential complement is not observable in French, since tensed sentential complements always require the presence of a complementizer, and since the complementizer que itself is not directly related to demonstrative pronouns. Nevertheless, there are some contexts in which a Focused sentential complement is doubled by a demonstrative pronoun $c e$ in a cleft sentence:

(24) a. Que les gens en ${ }_{i}$ disent du bien, c'est ce que Jean ${ }_{i}$ croit 'That people say nice things of him, that is what Jean believes'

b. Que les gens disent du bien de soi $_{\mathrm{i}} /{ }^{*}$ soi $_{\mathrm{i}}$-même, c'est ce que l'on $\mathrm{i}_{\mathrm{i}}$ croit 'That people say nice things of self, that is what one believes'

The sentences in (24) illustrate that the Binding properties of clefted sentential complements in belief contexts pattern exactly as those of attributed belief in (1416). It seems that clefting the sentential complement is sufficient to trigger a configuration of attributed belief. ${ }^{8} \mathrm{We}$ would like to relate this to the fact that the sentence is interpreted deictically, as illustrated by the demonstrative pronouns of the clefting construction.

In the framework of Pica (1996), the configuration in (21) is parallel to the structure of an epithet in the nominal domain, such as That little scoundrel of a linguist. Therefore, the complement of 'indirectly attributed' belief has to be viewed as a configurationally defined sentential epithet. This idea can be spelled out as follows: we take it that the judgmental relation expressed by the speaker between the attribute scoundrel and the noun phrase denoted by the NP a linguist is similar to the

7 See also Bolinger (1972) for other contexts in which that is obligatory. Bolinger's observations in (22) can be explained in terms of the attributed - directly attributed distinction, which, as we have stressed before, is just a special case of the crosslinguistically more widespread expression of direct and indirect evidentiality. The negation introduced by disbelieve in (22b) introduces a distance in the relation between the Experiencer and the belief contents. Since we have analyzed 'directly attributed' belief as direct 'possession' of an attitude, negation of that direct possession in disbelieve cannot be interpreted as 'directly attributed' belief, and hence must be viewed on a par with 'indirectly attributed' belief.

8 Interestingly, clefting the complement of a verb expressing propositional attitudes always forces the verb into an interpretation implying attributed or indirect belief. A verb of perception such as voir 'see' which can either refer to direct visual perception or indirect mental perception, only receives an interpretation of mental perception if its complement is clefted:

i. J'ai vu tout de suite que Marie était malade 'I saw/ understood immediately that Mary was sick'

ii. Que Marie était malade, c'est ce que j'ai vu tout de suite 'That Mary was sick, that is what I ??saw/ understood immediately' 
judgmental relation that holds in a relation of 'indirectly attributed' belief between a propositional contents and the Experiencer. In the case of 'indirectly attributed' belief, this configuration obtains by identification of the complementizer that, which we take to be a pronoun-like element, with the class of IPs in SpecCP. Identification of the pronoun that is achieved by movement of $\mathrm{C}^{\circ}$ to $\mathrm{D}^{\circ}$. The configuration for epithets applied here configurationally derives the interpretive effect that is present in 'indirectly attributed' belief sentences. 'indirectly attributed' belief sentences carry a strong judgment from the speaker on both the subject of belief and the sentential complement. With respect to the sentential complement, the judgment often implies that what the subject believes is in fact false. As a result the subject of that belief is presented as being naive, or simply ignorant of the 'real' state of things. In other words, the way in which the reference of the sentential complement is presented is radically different in a configuration of 'indirectly attributed' and 'directly attributed' beliefs.

The structure proposed in (21) easily derives weak island effects. In terms from the Barriers era (Chomsky 1986), we can say that only arguments whose trace is properly governed by the embedded verb will be able to move out of the sentential complement of 'indirectly attributed' belief, since SpecDP is occupied. Moving from $\mathrm{C}^{\circ}$ to $\mathrm{D}^{\circ}$, the lexical preposition at governs the IP in SpecCP: by lexically governing the IP in SpecCP, it allows for extraction out of it (Chomsky 1986). The absence of ECM is due to the configurational particulars of ECM in French: as is well known, ECM in French requires Wh-movement (Kayne 1981) or (covert) Focus movement (Pollock 1985, Rooryck 1995) of the embedded subject to or through the embedded SpecCP. Rooryck (1995) shows moreover that the subject of the infinitival complement of croire 'believe' in ECM contexts must receive Case within the embedded infinitive. We assume that ECM in French involves a context that is slightly different from (18) in that the entire CP moves to SpecDP, and does not involve the successive movement of IP presented in (17). Now, since 'indirectly attributed' belief as represented in (21) does require movement of IP to SpecCP, this position will not be available for the Focus or Wh- movement of the embedded subject of IP that is necessary for the ECM configuration. Hence, the ECM configuration cannot obtain.

The configuration also allows for an explanation of the fact that negative croire 'believe' does not trigger subjunctive mood in 'indirectly attributed' belief contexts. It is often assumed that subjunctive mood triggered by specific matrix verbs is mediated through the sentence-modality properties of $\mathrm{C}^{\circ}$. In the case of negative croire 'believe', $\mathrm{C}^{\circ}$ might for instance be viewed as a variable for the matrix negation, which triggers subjunctive as a result of the negative operator binding it (Rooryck 1992). In the framework outlined here, the mediation of subjunctive mood into the embedded clause must take place through $\mathrm{D}^{\circ}$, which determines the referential status of the sentence. We can assume that a $\mathrm{D}^{\circ}$ that is 'subjunctively determined' by the matrix negation can only license subjunctive mood through Spec-Head agreement with an IP in SpecDP at LF. This would account for subjunctive mood in cases of 'directly attributed' belief such as (12b), in which IP moves to SpecCP at LF, in accordance with the configuration in (18). Cases of 'indirectly attributed' belief, however, involve configuration (21), in which IP never moves to SpecDP, but remains in SpecCP. As a result, subjunctive mood in the IP will not be licensed, and the configuration supporting 'indirectly attributed' belief will only allow for (default) indicative mood. This then explains the absence of subjunctive mood in sentences involving 'indirectly attributed' belief such as (12c). 
It is important to underscore here that the requirement for indicative mood in 'indirectly attributed' beliefs is very strong evidence in favor of our claim that 'indirectly attributed' belief should be analyzed as a case of 'indirect' evidentiality. In various languages, evidentiality, mood, and aspect interact in various ways (cf. Chafe \& Nichols 1986). The special status of the complementizer in 'indirectly attributed' belief contexts (cf. supra) also suggests a strong relation between evidentiality, mood, and complementizer type.

The Binding facts can be related to the interpretive effects raised by the configuration. We had to explain why coreference of en is possible with the subject of the matrix clause. In an 'indirectly attributed' belief context, the subject of belief is not agentive, and can be fully interpreted as the Recipient of the attribution of belief. As a result, Binding between en and the subject of the matrix clause is possible.

With respect to soi, we have already observed that an anaphoric soi bound out of subjunctive clauses is radically different from the soi which is long distance bound out of an indicative clauses. The soi in indicative clauses as in (16) cannot be combined with même. The absence of même, which is a Focus-marker, suggests that soi here is already Focused. Focused soi needs an antecedent involving a certain eventive contrast. This is compatible with the subject of 'indirectly attributed' belief, which is not agentive, as we have argued, but still is involved in 'maintaining' the event, thus providing the necessary eventive contrast (Pica 1987 for French). ${ }^{9} 10$

9 The agentive character of croire 'believe' in contexts of 'directly attributed belief can be tested with agent-oriented adverbs:

i. Les généraux français ont nonchalamment cru que la ligne Maginot allait tenir

'The French general carelessly/ brazenly believed that the Maginot line would hold'

In combination with an adverb marking 'indirectly attributed' belief, the inclusion of agent-oriented adverbs becomes quite difficult.

ii. Les généraux français ont probablement (*?nonchalamment) cru que la ligne

Maginot allait tenir

'The French generals probably (carelessly/ brazenly) believed that the

Maginot line would hold'

As (iii) shows, this impossibility is not due to a more general constraint on combining agentoriented adverbs with probablement 'probably'.

iii. Jean a probablement nonchalamment jeté son mégot dans le foin

'Jean has probably carelessly thrown his cigarette butt into the hay'

We therefore conclude that this is good evidence of a difference in agentivity of the subject in 'indirectly attributed' (ii) and 'directly attributed' (i) belief.

10 The structure of 'indirectly attributed' belief also exists in the nominal domain: in the following structures, le linguiste des linguistes does not refer to a linguist belonging to the set of linguists, but to the best example of the class of linguists.

i. Jean est le linguiste des linguistes

[DP Le linguiste $\left[\mathrm{D}^{\circ} \mathrm{des}\right]\left[\mathrm{CP}[\mathrm{IP} \ldots\right.$ linguistes $\left.\left.]\left[\mathrm{C}^{\circ} \mathrm{t}_{\mathrm{de}}\right] \mathrm{t}_{\mathrm{IP}}\right]\right]$

This interpretation arises as the result of the identification by the speaker of le linguiste in SpecDP with the class of linguists in SpecCP, in the same way the complementizer/ demonstrative pronoun that in SpecDP of (20) is identified via $\mathrm{C}^{\circ}$ to $\mathrm{D}^{\circ}$ movement with the IP complement. In both cases, speaker judgment is expressed on the DP construction. 


\section{Extending the analysis: belief 'de se' and possession of beliefs}

We would now like to extend the analysis developed here to a special case of belief that has been first identified by Castañeda (1966). Castañeda (1966) defines belief 'de se' as a conscious belief held by the subject of belief about himself. Let us consider this as the core of belief 'de se'. Castañeda (1966) gives arguments showing that unambiguous belief 'de se' occurs in embedded sentences in which the subject corresponds to the variable he himself rather than the more ambiguous he. Castañeda (1966) shows that the pronoun he has many more uses besides that of a variable. Therefore, we will use reference to lui lui-même 'him himself' in French to identify sentences including 'de se' beliefs.

Rather unexpectedly, such sentences involve strong islands, as attested by the following sentences:

(25) a. Je me demande combien Jean croit qu'il a vu de musées

'I wonder how many Jean believes that he has seen museums'

b. * Je me demande combien Jean croit que lui lui-même a vu de musées

'I wonder how many Jean believes that he himself has seen museums'

(26) a. * Je me demande à quelle personne Jean croit que lui lui-même a offert des fleurs 'I wonder to which person Jean believes that he himself has offered flowers

b. * Je me demande ce que Jean croit que lui lui-même a offert à Marie 'I wonder what Jean believes that he himself has offered to Marie'

Binding data with soi and en are more difficult to obtain, since the subject of the embedded clause and the subject of the matrix are coreferential, thus preventing us from checking Binding at a distance. There are however some unusual cases of ECM, involving strong judgment on behalf of matrix subject, which we would like to assimilate to belief 'de se'. Sentences such as (27a) have been quoted by Ruwet (1983). Rooryck (1995) offers arguments showing that the complement of soupçonner 'suspect' in (27a) indeed involves an infinitive with an expressed subject rather than a context of control. The sentence (27b) is truly surprising, since ECM sentences with croire 'believe' in French usually require the subject of the infinitival complement to be Wh- moved (Kayne 1981) or Focused (Pollock 1985). The sentence (27b) is only possible in a context where the entire sentential complement of croire 'believe' is interpreted as carrying a strongly 'affective' or 'intensive' link to the subject of the matrix clause. Similarly, (27a) carries the interpretation that the judgment of the subject expressed in the complement of soupçonner 'suspect' is strictly his/ her own. ${ }^{11}$

11 A similar 'affective' or 'intensive' interpretation occurs in cases of inalienable possession in DP: Bonneau \& Pica (1995) note the contrast between *sa haine 'his hate and sa grande haine 'his great hate'. Similarly, 'affective' contexts allow for the anaphoric use of possessives with NPs such as haine 'hate', peur 'fear':

i. $\quad \operatorname{Jean}_{\mathrm{i}}$ ne comprend pas très bien $\mathrm{sa} * \mathrm{i} / \mathrm{arb}$ terrible peur.

'Jean does not understand very well his terrible fear'

ii. $\quad \operatorname{Jean}_{\mathrm{i}}$ n'arrive pas à contrôler $\mathrm{sa}_{\mathrm{i}} / \mathrm{arb}$ terrible peur.

'Jean is not able to control his terrible fear' 
(27) a. Je soupçonne [ce vin d'avoir trente ans de cave] 'I suspect that wine to have thirty years of cellar

b. On croit toujours dans for intérieur [son héros révolutionnaire préféré avoir été injustement condamné]

'One always deeply believes one's preferred revolutionary to have been injustly convicted

We want to analyze case such as (27) as cases of belief 'de se': in the same way as the embedded he himself strictly indicates belief about the matrix subject (the subject's own beliefs), the embedded sentences in (27) reflect a belief that is strictly about the subject him/herself.

A more formal argument to treat the sentences in (27) along the lines of (25-26), hence as belief 'de se', is that the sentences (27) constitute strong islands for extraction in the same way as (25-26):

(28) a. Je me demande à quelle peine on croit toujours (*dans son for intérieur) son révolutionnaire préféré avoir été condamnée

'I wonder to what punishment one always (deeply) believes one's preferred revolutionary to have been sentenced'

b. * Je me demande combien d'années il soupçonne ce vin d'avoir 'I wonder how many years he suspects that wine to have'

Now we have established the formal and interpretive relation between belief 'de se' in (25-26) and the more unusual ECM cases in (27), we can check the Binding properties of the sentences in (27). The Binding properties of these sentences are different from anything hitherto observed: en is entirely ungrammatical, contrary to cases of 'indirectly attributed' belief where they are fine, and to cases of 'directly attributed' belief where they are marginal. Long distance so $i$ 'self' must be obligatorily focalized by même, different from the cases of 'indirectly attributed' belief where même rendered the sentence ungrammatical, and to cases of 'directly attributed' belief where they are marginal.

(29) a. * $\mathrm{On}_{\mathrm{i}}$ croit toujours dans son for intérieur son révolutionnaire préféré en ${ }_{i}$ avoir dit du bien 'One always deeply believes one's preferred revolutionary to have said good things about self'

b. $\mathrm{On}_{\mathrm{i}}$ croit toujours dans son for intérieur ce genre de personnes $\mathrm{j}$ avoir dit du bien de soi $?_{\mathrm{i} / \mathrm{j}} /$ soi-même $_{\mathrm{i} / *_{\mathrm{j}}}$

'One always deeply believes that kind of person to have said good things about self'

(30) a. * $\mathrm{On}_{\mathrm{i}}$ soupçonne toujours ce genre de personnes de PRO en $\mathrm{n}_{\mathrm{i}}$ dire du mal 'One always suspects that kind of person to slander self'

b. $\mathrm{On}_{\mathrm{i}}$ soupçonne toujours ce genre de personnes de dire du mal de ?soi $\mathrm{i}_{\mathrm{i}} /$ soi-même

'One always suspects that kind of person to slander self'

Note that (30a) contains a PRO, which is a 'de se' pronoun. The comparison between the various properties involved in the three cases of belief we have hitherto distinguished can be made easier by the following overview: 


\begin{tabular}{|l|c|c|c|}
\hline & $\begin{array}{c}\text { Nonattributed' } \\
\text { belief }\end{array}$ & $\begin{array}{c}\text { 'Attributed' } \\
\text { belief }\end{array}$ & $\begin{array}{c}\text { 'de se' } \\
\text { belief }\end{array}$ \\
\hline Extraction & fine & weak island & strong island \\
LD en & $? ?$ & OK & $*$ \\
LD soi & $? / ? ?$ & OK & $?$ \\
LD soi-même & $? / ? ?$ & $*$ & OK \\
\hline
\end{tabular}

The overview raises the question as to how the syntactic properties of belief 'de se'. can be configurationally explained along the lines of the configurations provided for 'attributed' and 'nonattributed' belief. We would like to represent the configuration of belief 'de se' (inalienable possession) as follows:

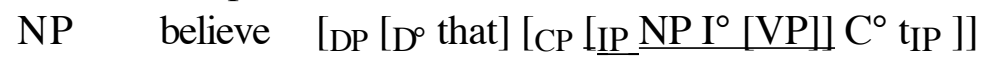

This structure, unlike the structure (21) representing 'attributed' belief, involves no movement of a prepositional $\mathrm{C}^{\circ}$ to $\mathrm{D}^{\circ}$. As a result, the complementizer that has no lexical element that has incorporated into it. As it is a purely functional element, our analysis correctly predicts that the complementizer that can be suppressed in de se contexts: John believes (that) he himself is a millionnaire. The complementizer that now resembles the definite determiner of inalienable possession which appears on the inalienable noun in I hit John on the nose. Since the IP in SpecCP is not governed by a lexical element, it becomes a strong island for extraction. The strong island effects observed above can thus be derived.

Interestingly, the configuration in (33) has properties of both attributed and nonattributed belief. It resembles nonattributed belief in that the complementizer is a functional element which can be deleted, and it resembles the configuration of attributed belief in that IP cannot move further than SpecCP. Moreover, the subject of 'de se' belief is certainly not a Recipient of its belief as required for attributed belief, but nevertheless the sentential complement of 'de se' belief must involve a strong judgment, as for attributed belief. This particular intermediate status is probably due to the fact that 'de se', or 'pseudo-attributed' belief as we would like to call it, in fact involves a case of attributed belief which displays nonattributed characteristics because of the reflexive nature of self-attribution.

Let us now turn to the Binding properties in 'de se' belief. There is no question that 'de se' belief is predicated of an agentive, controlling, entity. As a result, Binding by $e n$ as in (30a) is ungrammatical, since one of the independent restrictions on the antecedent of $e n$ is that it requires nonagentive long distance antecedents, as illustrated in (33) (cf Ruwet 1991):

(34) a. * Jean veut qu'on en $_{\mathrm{i}}$ dise du bien

'Jean wants that people say nice things about him'

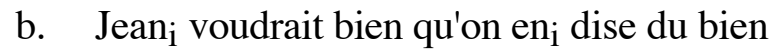

'Jean would like that people say nice things about him'

Long distance Binding of soi as in (30b) is less acceptable than Binding of soimême. Let us first point out that the degraded status of soi cannot be due to the strong island character of the sentential complement, which might prevent soi 'self' from moving long distance at LF to its antecedent. Recall that the sentential complement needs to contain an anaphor bound from without. Rather we would like to attribute the degraded status of soi to the fact that it is interpretively neutral in that 
it expresses no judgment. Bonneau \& Pica (1996) have shown that possessive son/ $s a$ 'his/her' in French only functions as a long distance anaphor if its DP contains an adjective expressing a judgment.

(35) Personne ${ }_{i}$ ne souhaite que l'on dise du mal de $\mathrm{sa}_{\mathrm{i}} *$ (terrible) haine

'Nobody wishes that people slander their (terrible) hate'

Contrary to soi, soi-même contains the intensifier même, which plays the same role as the adjective in (35) in making the long distance anaphoric interpretation available.

\section{Conclusion}

In this paper, we have tried to show that the propositional attitude expressed by a verb such as believe should in fact be subdivided into three very distinct subcases: 'directly attributed' belief, 'indirectly attributed' belief, and 'de se' belief. We have shown that each type of belief not only displays a very specific syntactic behavior with respect to extraction and Binding, but that they each also feature specific interpretive effects. We argue that both the syntactic properties and the interpretive effects of these three types of attitude can be explained by the specific configuration of the sentential complement of believe. Moreover, the three types of belief can be reduced to the three basic types of possession distinguished by Bonneau \& Pica (1995).

The facts and their analysis might seem quite exotic at first sight. It should be observed, however, that in many languages, embedded sentences feature different types of complementizers reflecting the direct or indirect nature of the evidence available to the matrix subject for the propositional contents of the sentence (Frajzyngier 1995). We suggest that such facts can be ultimately reduced to an analysis along the lines of that developed here, and serve as a reminder of how small the variation among languages actually is.

Other attitudes (perception, doubt) can be shown to equally involve different interpretive effects and syntactic peculiarities. If we take the case of perception verbs, it is well known that these allow for interpretations of direct perception through the senses (I saw the car slam into the tree), and indirect perception through mental analysis (I can see your point/ how your analysis derives that). We think that an analysis similar to the one developed here for believe will no doubt prove fruitful for these cases as well. For lack of space, we have to leave this issue for further research.

For now, we hope to have shown that certain facts, commonly attributed to human experience and said to be outside the realm of the Grammar, can be described in configurational terms within the minimalist program. In further research, we hope to find out whether the phenomena described here are indeed entirely determined by configurational conditions, and to what extent they might be related to interface conditions.

\section{References}

Benveniste, Émile. 1966. Problèmes de linguistique générale I, Gallimard, Paris. Bolinger, Dwight. 1972. That's that. Mouton: The Hague.

Bonneau, José \& Pierre Pica. 1995. From 'appertainence' to possession: predicative and internallyheaded relative constructions in French nominals. to appear in Lingua. 
Castañeda, Héctor-Neri. 1966. 'He': a study in the logic of self-consciousness. Ratio 7.130-157.

Chafe, Wallace \& Johanna Nichols. 1986. Evidentiality: the linguistic coding of epistemology. Norwood, N.J. : Ablex.

Chomsky, Noam. 1992. A Minimalist Program for Linguistic Theory, in K. Hale, \& J. Keyser (eds), The View from Building 20, MIT Press, Cambridge Mass.

Chomsky, Noam. 1993. Language and thought. Moyer Bell, Wakefield, RI \& London

Déchaine, Rose-Marie, Teun Hoekstra, \& Johan Rooryck. 1995. Augmented and non-augmented HAVE. Proceedings of Langues et Grammaire 1, Paris VIII. ed. by Léa Nash \& Georges Tsoulas.

Frajzyngier, Zygmunt. 1995. Two complementizers in Lele. Studia Chadica et hamitosemitica, ed. by Dymitr Ibrismow \& Rudolf Leger, Rüdiger Köppe Verlag 163-170.

Freeze, Ray. 1992. Existentials and other locatives. Language 68.553-595.

Hoekstra, Teun. 1993. HAVE as BE plus or minus. ms. HIL/Leiden University.

Khalaily, Samir. 1996. 'He himself' in the subject position of the complement of propositional attitude verbs, and the Binding theory. (ms. Leiden University/ HIL)

Kayne, Richard. 1981. On certain differences between French and English. Linguistic Inquiry, 12.349-371.

Kayne, Richard. 1993. Toward a modular theory of auxiliary selection. Studia Linguistica 47.

Kayne, Richard. 1994. The antisymmetry of syntax. Cambridge: The MIT Press.

Pica, Pierre. 1987. On The Nature of the Reflexivization Cycle. In: J. McDonough, B. Plunkett (eds.), Proceedings of the 17th Conference of the North Eastern Linguistic Society. Amherst: GLSA.

Pica, Pierre. 1996a. Anaphoric Words. Ms. Paris \& Montreal.

Pica, Pierre. 1996b. Quelques éléments pour une typologie de l'accord verbal, assortis de quelques remarques dans le débat linguistique contemporain. In: Faits de langue - L'accord. Paris: Ophrys .

Pollock, Jean-Yves. 1985. On case and the syntax of infinitives in French. Jacqueline Guéron, Hans-Georg Obenauer \& Jean-Yves Pollock. Grammatical representation. Dordrecht: Foris, 293326.

Postal, Paul. 1974. On raising. Cambridge: MIT Press.

Rooryck, Johan. 1992. Negative and factive islands revisited. Journal of Linguistics 28.2

Rooryck, Johan. 1995. On the interaction between Raising and Focus in sentential complementation. ms. Leiden University/ HIL.

Ruwet, Nicolas. 1983. Montée et contrôle: une question à revoir? Revue Romane (numéro spécial) 24.17-37.

Ruwet, Nicolas. 1992. En et Y : deux clitiques pronominaux antilogophoriques. Langages, 97.

Salmon, Nathan \& Scott Soames. 1988. Propositions and attitudes. Oxford: Oxford University Press.

Sigurdsson, Halldor. 1990. Long distance reflexives and moods in Icelandic. Modern Icelandic Syntax. Syntax and Semantics 24, ed. by Joan Maling \& Annie Zaenen, New York: Academic Press, 309-346. 